\title{
The ethical dimension of travel agencies business in changing business environment (Serbia) - employees' attitudes vs. employees' conduct expected by management
}

\author{
Karolina Simat ${ }^{\mathrm{A}^{*}}$, Aleksandra Dragin ${ }^{\mathrm{A}}$, Vanja Pavluković ${ }^{\mathrm{A}}$, Slobodanka Markov ${ }^{\mathrm{A}}$ \\ Received: March 14, 2018 | Revised: October 02, 2018 | Accepted: October 29, 2018 \\ DOI: $10.5937 / g p 23-16828$
}

\begin{abstract}
The purpose of the paper is to provide an empirical study of employees' ethical behavior in travel and tourism industry. A survey research was done in 2012 in the Republic of Serbia among employees in travel agencies as one of the most important subjects in heterogeneous structure of travel and tourism industry, using a questionnaire designed according to the basic theoretical principles of professional ethics. Dealing with the issue of ethical responsibility of employees in travel agencies, this work examines whether employees have business ethics awareness and what kind of individual and corporate social responsibility as part of business environment is undertaken in this regard. The findings of the study showed that employees of travel agencies are ready to act in an ethical manner, although it is the opposite of management attitudes in specific situations. Finally, the paper provides a critical evaluation of entrepreneurial activities and obstacles that travel agencies encounter while operating in the Serbian economy in transition.
\end{abstract}

Keywords: etical responsibility; business environment; ethical management; travel agent

\section{Introduction}

Entrepreneurship is the cornerstone of a modern competitive economy. Because of the economic and social importance attributed to entrepreneurship, every country has adopted policies aiming to encourage and to support business environment. Ethical responsibilities require that businesses follow the modes of conduct considered as morally right (Botescut et al., 2008; Carroll, 1991; Țigu \& Țuclea, 2008). Lewis defines business ethics as rules, standards, codes or principles, which provide guidelines for morally right behavior and truthfulness in specific situations (Lewis, 1985). It is about fairness and decision what is right or wrong, about defining the practices and rules, which underpin responsible conduct between individuals and groups (Connock \& Johns, 1995).

According to Belas (2012) companies are seen as human communities using social practices to achieve common social objectives. These objectives are implemented through a relationship of trust and authentic, transparent customer relationships.

Based on these definitions, a socially responsible organization must try to make a profit as well as obey the law and be ethical (Blesic et al., 2013; Olaru et al., 2011). Frunza (2011) emphasizes that in addition to ethical di-

\footnotetext{
A University of Novi Sad, Faculty of Sciences, Department of Geography, Tourism and Hotel Management Faculty of Sciences,Trg Dositeja Obradovića 3, 21000 Novi Sad; aleksandra.dragin@dgt.uns.ac.rs; vanja.dragicevic@dgt.uns.ac.rs; slobodanka.markov@gmail.com

* Corresponding author: Karolina Simat; e-mail: simatka@gmail.com
} 
mension, social responsibility has also an important legal dimension, given the fact that any action should be carried out in a legal framework determined by the economic environment in which it takes place.

The term of corporate social responsibility (CSR) has long evolution beginning in the 1950s. Bowen (1953) set forth an initial definition of the social responsibilities of businessmen: "It refers to the obligations of businessmen to pursue those policies, to make those decisions, or to follow those lines of action which are desirable in terms of the objectives and values of our society". However, up to date, there is no single, generally accepted definition; that indicates its complexity. The concept of CSR is intensively discussed over the last fifty years, resulting in various definitions of this concept - from wider definitions, with emphasis on behavior that includes social improvement beyond the company's interests, to the point where the focus is on economic benefits to stockholders (McWilliams \& Siegel, 2006). Socially responsible business is traditionally conceived quite broadly as "managerial obligations to take measures to protect and promote society, viewed as a whole and in relation to (in the interest of) the organization" (Davis \& Blomstrom, 1975). Also, the notion of socially responsible business deals with "bringing corporate behavior to the level where it matches the currently prevailing social norms, values and expectations of performance" (Sethi, 1979). In the current business environment in the Republic of Serbia, considering the overall state of the economy, it is difficult to find an appropriate approach to moral dilemmas. According to the Smart Kolektiv research (2007), there is still lack of consumer awareness related to social responsibility of business in Ser- bia. This problem is particularly conspicuous in the service industry, where the human factor has an important role. Scandals in Serbian tourism industry are common, originated just on the base of unethical conduct of travel agencies, through a variety of consumer and business co-workers frauds during the high season. Travel agencies are just the main actors (Ministry of Finance and Economy, 2010). In that sense, there is an open question of the individual, corporate as well as government social responsibility. Novi Sad is not only a remarkable example of an area in which the number of ethnic communities reflects cultural, religious, ethnic as well as political diversity, leading to contacts of different cultural and moral values, but also the second city in the Republic of Serbia by the number of travel agencies and tour operators, both inbound and outbound. A lack of research on this topic in the region of the Balkans with transitional economies inspired the authors to conduct study on socially responsible business of Serbian travel agencies. Is staff in travel agencies, as the most important business actors in tourism industry, aware of the importance of their activities in accordance with the ethical standards and principles and taken responsibility? Are they ready to act in an ethical manner if it is not expected from management, or if they were willing to act in an ethical manner if that would be an opposed to management in a particular situation? Comparing ideological and operational perspectives of CSR will reveal pivotal aspects of potential and actual conflicts relevant to CSR as well as indicate appropriate measures needed for improvements in ethical business practice in tourism market structure in Serbia as well as the region.

\section{Literature review}

Considering exponential growth of tourism industry in the world and the obvious need to take into account ethical dimension of agency business in changing business environment, in recent decades the business social responsibility of main stakeholders in tourism industry attracts the attention of many authors (Miller, 2001; Gordon \& Townsend, 2001; Kalisch, 2002; Briedenham, 2004; Budeanu, 2005; Yaman \& Gurel, 2006; Minciu, 2008). However, tourism as a service industry, unlike the manufacturing, requires much more qualitative and human relations. The tourist leaves its everyday 'safe' environment during a journey, and the most important existential questions are left to travel agent, whose role then becomes substantial and ethically sensitive. The scientific literature increasingly highlights the role of the ethical dimension of decision making in achieving corporate social re- sponsibility (CSR) of travel agencies (Fennel \& Malloy, 1999; Lovelock, 2004, 2008; Simat et al., 2012; Simat \& Dragin, 2012). Some authors propose the induction of the issue in high education, training and personal selection as well as ethical behavior promotion in order to encourage awareness of the importance of personal and professional ethics in tourism (Enghagen, 1990; Enghagen \& Hott, 1992; Richter \& Richter, 1999; Vallen \& Casado, 2000; Hudson \& Miller, 2005; Jovicic et al., 2011).

In order to clarify the concept of social responsibility, Zenisek (1979) developed a model for CSR based on an understanding of ethics. According to Zenisek (1979) ethics is a belief system with associated behaviors. People do not always behave the way they believe. The model has three perspectives: (1) ideological, or what a corporation's managers believe the firm 
should be doing; (2) societal, what the firms' external stakeholders' expect; and (3) operational, the examination and measurement of what the corporations actually perform (Arthaud Day, 2005). Zenisek's model allows for critical understanding of the issues related to performing CSR (Arthaud Day, 2005). While most CSR studies use only one perspective, Arthaud Day (2005) emphasized the significance of comparing two perspectives because it helps to understand the pivotal aspects of potential and actual conflicts relevant to CSR. Most of all, comparing what people believe is CSR and what the corporations are actually doing is important because CSR activities of an organization can be more meaningful and effective when they match people's beliefs. An organization can garner better support from managers when its CSR activities are in line with their managers' perceptions (Kim, 2009). However, Belas notices that the acceptance of moral principles in business is not integrated into the management decisions of firms, and it cannot be expected that selfregulatory ethical business tools (such as CSR) will be effective (Belas, 2012).

Considering the importance of existence and implementation of ethical principles in tourism, the World Tourism Organization to the United Nations (UNWTO) adopted the Global Cod of Ethic for Tourism at the thirteenth General Assembly in 1999 in Santiago (Chile). This document was adopted at the UN General Assembly in 2011, recognizing the role of tourism not only in poverty reduction but also in improving quality of life of mankind. Its potential lies primarily in the contribution to economic and social development, especially in developing countries. UNWTO also recognizes tourism as a phenomenon that promotes international understanding, peace and prosperity. Therefore the Code covers a wide variety of application areas, as customer protection, corporate responsibility, both child protection and the most vulnerable population, cultural and ecological protection, dialogue between cultures, tourism as a beneficial activity for host countries and communities, specified obligations of stakeholders in tourism development, then rights of the workers and entrepreneurs in tourism industry, as well as the vision of tourism as a factor in development and promotion of fundamental human rights, in accordance to the United Nations Millennium Development Goals (Global Code of Eth- ics for Tourism, 1999). Recognizing the worldwide inefficient implementation of business ethics in tourism, Spanish General Secretariat of Tourism and Domestic Trade and WTO has organized the 'First International Congress on Ethics and Tourism' in September 2011 (First International Congress, 2011).

Although Global Cod of Ethic for Tourism exists as an official document in Serbian language, its implementation in society and economy of Republic of Serbia surprisingly doesn't govern any national law. Some indications of its implementation can be identified in the Law on Tourism of Republic of Serbia ("Law on Tourism", 2010), Law on Consumer Protection of Republic of Serbia ("Law on Consumer Protection", 2010) and other legislative documents. However, there is a growing number of scientific meetings in Serbia addressing business ethics in tourism industry. Pioneering researches on the subject were given by some authors, analyzing ethics in providing tourism services (Jovicic et al., 2011; Miskovic, 2012; Simat \& Dragin, 2012). Miskovic (2012) indicates the necessity to establish the codes of conduct for all professionals who are in direct contact with tourists in Serbia, while Jovicic et al. (2011) indicate the need for existence and an appropriate implementation of ethical principles for all stakeholders both directly and indirectly involved in tourism industry.

The above overview indicates that the Global Cod of Ethic for Tourism implementation in Serbia is still left to the individual. Whether employees in travel agencies in Serbia are ready to act in an ethical manner if it is not expected from management, or if they were willing to act in an ethical manner if that would be an opposed to management in a particular situation? The main hypothesis of this work is that there is statistically meaningful difference between personal ethics and expected business conduct imposed by company management. In this regard, it is necessary to measure ethical responsibility of employees and social responsibility using actual responsible activities or behaviors of employees in travel agencies, comparing to expected activities by management in their everyday tasks.

Objective comprehension of the issues in this study will provide pioneer results on the attitudes of employees vs. management expectations and indicate appropriate measures needed for improvements in business ethics practical application in tourism market structure in Serbia as well as the region.

\section{Research objectives}

With the above general problem in mind, the purpose of this study is three-fold: first to more precisely determine ethical values considered as acceptable in the business of travel agencies, specifically in Novi
Sad; second to determine if there is statistically significant difference between personal attitudes of employees on ethical/unethical practice and conduct expected by management in the same particular situations; 
and third to analyze identified ethical values in relation to basic concepts of professional ethics theory. In that sense, the focus of discussion will be on the ethical dimension in the conduct of employees in travel agencies in Novi Sad which should have the most decisive influence on travel agencies' business policy. This research is a part of the doctoral dissertation (PhD student Karolina Simat - Department of Geography, Tourism and Hotel Management, Faculty of Sciences, University of Novi Sad).

\section{Research methods}

\section{Data collection and sample}

The research was completed in 2012. Data was collected using designed questionnaire according to the basic theoretical principles of professional ethics (Connock \& Johns, 1995; Daft, 2006; De George, 1987, 2003; Drummond \& Bain, 2001; Fisher, 2003; Goldman, 1980; Hall, 1992; Karpati, 2001; Nordstrom \& Ridderstral, 1999; Shaw, 1991; Stark, 1998; Trevino \& Nelson, 1999; Weeden, 2002). Ethical/unethical scenarios in the form of statements in particular situations were taken from Business Etiquette (Robinson, 200o) and used to develop original questionnaire and descriptive scale of answer evaluation.

A random sample of 35 travel agencies in Novi Sad included 52 self-selected employees of different gender, age, educational level and field of education, who identified themselves as willing to be involved in further research on the topic. After conducting field research, authors checked filled questionnaires, and five polls were excluded from further processing. The final analysis is based on 47 valid, appropriately completed questionnaires. Among the travel agencies included in the research, 25 travel agencies are members of the National Association of travel agencies in Republic of Serbia, which represents $76 \%$ of the total members in Novi Sad (National Association of Travel Agencies in Republic of Serbia, 2011).

We used the the SPSS software (version 11.0). Descriptive statistics was used to present the results of socio-demographical characteristics of employees, their aspects of ethical/unethical conduct and expected standards of business conduct in their organization. The paired samples t-test was used to analyze differences between personal attitudes of employees towards ethical/unethical conduct and conduct expected from management.

\section{Description of variables and scale measurement}

The responses used for analysis were divided into several thematic groups. The first one includes socio-demographic characteristics of respondents. The second group of answers refers to respondents attitudes towards implementation of business ethics in travel agencies. In this part of questionnaire, respondents were asked to confirm accuracy of 17 offered statements using answers 'always' (score 1), 'sometimes' (score 2) and 'never' (score 3) in order to determine how often employees believe they comply with ethical principles in performing everyday tasks. The following unity of analyzed answers was used to indirectly check the previous statements. It was reached by determining the extent to which the employees are acting ethically in their everyday work activities, and what are the expected standards of business conduct in travel agencies in Novi Sad. These questions are in the form of reviews in extent to which management insists on ethical behavior of employees. The respondents were asked to confirm accuracy of 7 offered statements using answers 'always' (score 1), 'sometimes' (score 2) and 'never' (score 3).

Due to lack of systematic approach to the study on the issue in the Republic of Serbia, a comparative analysis was not possible to be carried out, so obtained results were analyzed in relation to the basic assumptions of professional ethics. Synthesis of the most frequent responses of each individual statement led to the pioneering scientific cognitions in the field of business ethics in travel agencies in Serbia and employee attitudes.

\section{Results and discussion}

\section{Analysis of basic indicators}

Socio-demographic characteristics of employees in travel agencies in Novi Sad are shown in Table 1. Conducted research has indicated a higher proportion of employed females in travel agencies in Novi Sad ( $87 \%$ of the respondents). Most respondents are of the age group from 18 to 32 years, having a high education degree mostly in tourism (69\%) and econ- omy $(11 \%)$ and work at the current work place less than 5 years.

According to interviewers' opinion, employees in travel agencies were willing to answer the questions. Furthermore, it was observed that a discussion was opened among employees in some travel agencies on the topic of ethical/unethical practices immediately after completing the questionnaire. 
The ethical dimension of travel agencies business in changing business environment

(Serbia) - employees' attitudes vs. employees' conduct expected by management

Table 1. Socio-demographic characteristics of subjects

\begin{tabular}{|c|c|c|c|}
\hline Characteristics & Category & $f_{i}$ & Relative frequency (\%) \\
\hline \multirow{2}{*}{ Gender } & Men & 6 & 13 \\
\hline & Women & 41 & 87 \\
\hline \multirow{3}{*}{ Age } & $18-32$ & 37 & 79 \\
\hline & $33-48$ & 8 & 17 \\
\hline & $49-64$ & 2 & 4 \\
\hline \multirow{5}{*}{ Education } & Secondary & 3 & 6 \\
\hline & Diploma of higher education & 7 & 15 \\
\hline & Bachelor & 31 & 66 \\
\hline & Master/Magister & 6 & 13 \\
\hline & Doctoral & 0 & 0 \\
\hline \multirow{8}{*}{$\begin{array}{l}\text { Field of } \\
\text { education }\end{array}$} & Natural science & 2 & 4 \\
\hline & Social science & 3 & 6 \\
\hline & Technical science & 1 & 2 \\
\hline & Economic science & 5 & 11 \\
\hline & Tourism & 32 & 69 \\
\hline & Geography & 2 & 4 \\
\hline & Art & 1 & 2 \\
\hline & Linguistics & 1 & 2 \\
\hline \multirow{5}{*}{$\begin{array}{l}\text { Work } \\
\text { experience in } \\
\text { tourism }\end{array}$} & $<1$ year & 3 & 6 \\
\hline & $1-5$ years & 24 & 51 \\
\hline & $6-10$ years & 15 & 32 \\
\hline & $11-20$ years & 3 & 6 \\
\hline & $>20$ years & 2 & 4 \\
\hline \multirow{5}{*}{$\begin{array}{l}\text { Years of service } \\
\text { in current TA }\end{array}$} & $<1$ year & 4 & 9 \\
\hline & $1-5$ years & 26 & 55 \\
\hline & $6-10$ years & 14 & 30 \\
\hline & $11-20$ years & 3 & 6 \\
\hline & $>20$ years & 0 & 0 \\
\hline
\end{tabular}

Source: Outputs of experiment conducted and analysed by the author

Talking to people in leadership positions led to the information that an ethical behavior in the organization is mainly achieved by defining the principles and rules of conduct for employees. In addition, ethical behavior can be achieved by positive example of managers or superiors. Aforementioned people in leadership positions beard out that the ethical behavior in certain situations can be achieved by sanctioning. However, in this study, there has not been any one travel agency whose policy is based on education and training in order to help to employees to resolve ethical dilemmas in everyday business tasks and thus encourage their awareness of business ethics.

When asked whether it is important that the travel agencies and its employees always apply the principles of BE, $89 \%$ of employees responded that it was extremely important. However, the remaining $11 \%$ believe that business ethics implementation is important only in certain situations, because ethical behavior does not always lead to a good outcome. An important finding is that among the respondents there is no one who believes that the business ethics implementation in tourism industry is completely unnecessary.

\section{Employee's conduct in travel agencies in Novi Sad}

Table 2 shows some aspects of ethical/unethical conduct of employees towards the travel agency they work for, colleagues, clients and ethical/unethical conduct of management toward employees. Considering the personal ethical behavior of employees, at first glance our study has shown a high level of ethical behavior in many aspects within the collective. Thus, two-thirds of surveyed employees take pride in the agency they work for. Extremely high percentage of respondents (85\%) believe that they have contributed to positive image of travel agency they work for and more than two-thirds of those respondents always focus their time, energy and resources on improving products and services. 
Table 2. Conduct of employees in travel agencies in Novi Sad

\begin{tabular}{|c|c|c|c|}
\hline \multirow{2}{*}{ Accuracy of statements } & \multicolumn{3}{|c|}{ Relative frequency (\%) } \\
\hline & Always & Sometimes & Never \\
\hline \multicolumn{4}{|l|}{ Ethical conduct of employees: } \\
\hline $\begin{array}{l}\text { I'm proud of the travel agency where I work and I } \\
\text { commend it to anyone }\end{array}$ & 68 & 32 & 0 \\
\hline $\begin{array}{l}\text { As an individual I contribute to a positive image of my } \\
\text { travel agency }\end{array}$ & 85 & 15 & 0 \\
\hline $\begin{array}{l}\text { I concentrate my time, energy and resources on } \\
\text { improving products and services of my travel agency }\end{array}$ & 72 & 23 & 4 \\
\hline $\begin{array}{l}\text { I relate to all customers equally, regardless of race, } \\
\text { religion, nationality or gender }\end{array}$ & 96 & 4 & 0 \\
\hline $\begin{array}{l}\text { I try to avoid emotions, intolerant and insulting } \\
\text { behavior during contact with client/ business partner }\end{array}$ & 85 & 13 & 2 \\
\hline $\begin{array}{l}\text { I try to be polite no matter how annoying some } \\
\text { person is and no matter if I don't like her/him }\end{array}$ & 89 & 11 & 0 \\
\hline $\begin{array}{l}\text { When a customer complains, I deal with the } \\
\text { complaint firmly and fairly }\end{array}$ & 100 & 0 & 0 \\
\hline $\begin{array}{l}\text { The work of all employees is valued under equal } \\
\text { standards }\end{array}$ & 51 & 34 & 15 \\
\hline $\begin{array}{l}\text { I have the same opportunities for job advancement as } \\
\text { my colleagues }\end{array}$ & 68 & 30 & 2 \\
\hline \multicolumn{4}{|l|}{ Unethical conduct of employees: } \\
\hline $\begin{array}{l}\text { I present products of my travel agency better than } \\
\text { they in fact are }\end{array}$ & 21 & 36 & 43 \\
\hline $\begin{array}{l}\text { I bad-mouth competition in order to achieve success } \\
\text { of my travel agency }\end{array}$ & 2 & 4 & 94 \\
\hline $\begin{array}{l}\text { I ingratiate with management in order to progress in } \\
\text { work }\end{array}$ & 4 & 11 & 85 \\
\hline I tolerate unethical behavior of colleagues at work & 0 & 55 & 45 \\
\hline $\begin{array}{l}\text { I blindly obey authority even when misconduct is } \\
\text { obvious }\end{array}$ & 6 & 38 & 55 \\
\hline \multicolumn{4}{|l|}{ Management in travel agencies conduct toward employees: } \\
\hline I am under threat of dismissal & 0 & 21 & 79 \\
\hline $\begin{array}{l}\text { I am constantly overloaded with work and unable to } \\
\text { use vacation }\end{array}$ & 21 & 39 & 40 \\
\hline I suffer humiliation at work by supervisors & 2 & 30 & 68 \\
\hline
\end{tabular}

Source: Outputs of experiment conducted and analysed by the author

Unethical practice is mainly focused on achieving the best results of travel agency in tourism market and personal career development. Without doubt, there is a concern that more than a half of employees $(57 \%)$ always, or sometimes, present the travel agency they are working for better than it actually is. However, taking such unethical actions leads to the deliberately misleading clients. This often results in disappointing experience of the clients or they feel that they are played out with inadequate quality for the price they accepted to pay. Customer dissatisfaction could lead to bad reputation and/or customer loss. Furthermore, dissatisfied customer could make far-reaching negative consequences on the future performance of the agency. Kotler (2003) says "According to one study, disap- pointed customers bad-mouth the product to eleven acquaintances, while satisfied customers may goodmouth the product to only three". It is necessary to be familiar with competition, because this is a way to meet its own comparative advantages or disadvantages. In Table 2 it can be seen that the majority of employees in travel agencies never bad-mouth the competition ( $94 \%$ of respondents).

In terms of relationship with clients, all respondents declared that they deal decisively and fairly about customer complaints. Almost all employees of travel agencies treat their clients equally, regardless of race, religion, nationality or gender ( $96 \%$ of respondents). Most respondents (85\%) avoid emotion, intolerant and insulting behavior during contact with a cli- 
ent or business partner. According to observed data, almost $90 \%$ of respondents endeavor to be polite no matter how much they dislike the customers or being annoyed with them. During a personal conduct with client or business partner, participants usually lose control and a reasonable conversation can turn into insulting each other. Travel agent must be aware of that the manifestation of emotions during business conversation is one thing, while strategy of effective persuasion is another thing. If a person loses control over itself, almost certainly its' prudence would lead to the question. Many business relationships have been permanently disrupted due to things that have been spoken in this state (Robinson, 2000).

Based on the results shown in Table 2, it can be concluded how often the employees apply their personal ethics in their relationship with colleagues. As it can be seen, $85 \%$ of respondents never ingratiate to superiors. Almost half of the examinees, precisely $45 \%$ never tolerate unethical behavior of colleagues in the workplace, while the rest of $55 \%$ do it only sometimes. However, there is a concern that $38 \%$ of employees involved in the survey sometimes and $6 \%$ always obey to authority even though it is obviously an unethical conduct. Based on the above findings, it can be concluded that the relationship between employees in travel agencies in Novi Sad cannot be considered as very successful.

What kind of relationship do travel agencies and supervisors have with employees? It can be concluded on the basis of the following findings. Slightly more than one-fifth of employees are sometimes under threat of dismissal, and nearly two-thirds of employees are constantly or occasionally overloaded with work and unable to use vacation. Also, the findings indicate that work of all employees is not valued under equal standards, which reveals unethical corporate conduct toward employees. The same opportunity for job advancement as their colleagues believe having $68 \%$ of the employees. Jakopec and Susanj (2014) suggest that trust in leadership significantly decreases (and is the lowest) in situations when employees perceive the supervisors' allocation of interpersonal treatment as unfair.

The previous finding is compatible with the following. Also, less than a third of respondents suffer humiliation at work by supervisors, but there is a part of them (2\%) that is under constant pressure of humiliation. Such forms of ethical dilemmas manifest mobbing as a form of unethical conduct. Mobbing is one of the most serious problems that employee face in workplace and it can significantly disrupt human relationships and create serious problems referring to work environment. The issue of mobbing prevention at work in the region is particularly relevant topic in recent years. One of the most important activities is an adoption of the Law on the Prohibition of Abuse at Work by the Ministry of Labor and Social Policy of Republic of Serbia in 2010 ("Law on the Prohibition of Abuse at Work", 2010).

\section{Internal policy of travel agencies in Novi Sad}

The following analysis, among other things, aims to look at aforementioned assertions from a different angle. Considering expected conduct in travel agencies in Novi Sad, the following analysis also indicate if personal values preferably influence business ethics of travel agencies or internal company policy dictates personal conduct of employees in performing everyday tasks, taking into account if it is in some cases an opposite to personal ethical attitudes. Although all respondents have reported that they were expected to provide a high-quality, clear and credible information to potential customer (Table 3), in Table 2 it can be noticed that every fifth employee always display products of travel agency he/she is working for better than they in fact are, while every third does it sometimes. Table 3 also shows that $70 \%$ of respondents are always expected to indicate to potential customer the relationship between price and quality of a particular product/service he is interested in. Most of respondents (91\%) never conceal risks of product/service use, but $9 \%$ are expected to be silent about the risks. In addition, $79 \%$ of employees never hide or keep silent about features of product/service that may discourage a potential customer from purchase.

The presented data suggest that a significant number of employees in travel agencies have an unethical behavior related to customers, mainly by displaying products/services of travel agencies better than they really are. Concealing not only relevant information about prices but also risks of using certain product is an alarming fact. The above contradictory responses indicate an underdeveloped business ethics in travel agencies. Insufficient understanding of the business ethics issues among employees in travel agencies is result of the lack of business ethics training by management as well as the lack of the appropriate regulation by relevant government body. The conditions given above raise the question of efficiency of this "employee army" in crisis situations, which is common in tourism.

The following responses are characterized by contradictions. In this regard, as can be seen in Table 2, $100 \%$ of respondents answer "always" to the statement "When a customer complaints, I deal with it firmly and fairly". Surprisingly, out of all respondents, $23 \%$ sometimes ignore inconvenient questions, remarks and complaints of customers, just because this act is expected of them. If we generalize the findings of the 
Table 3. Expected standards of business conduct

\begin{tabular}{|c|c|c|c|c|}
\hline \multirow{2}{*}{\multicolumn{2}{|c|}{ Accuracy of statements }} & \multicolumn{3}{|c|}{ Relative frequency (\%) } \\
\hline & & Always & Sometimes & Never \\
\hline \multicolumn{5}{|c|}{ By doing my daily work tasks I am expected to: } \\
\hline \multirow{2}{*}{$\begin{array}{l}\text { Ethical } \\
\text { expectations }\end{array}$} & $\begin{array}{l}\text { provide high-quality, clear and credible information to potential } \\
\text { customer }\end{array}$ & 100 & 0 & 0 \\
\hline & $\begin{array}{l}\text { indicate to potential customer the relationship between price and } \\
\text { quality of a particular product/service he/she is interested in }\end{array}$ & 70 & 30 & 0 \\
\hline \multirow{5}{*}{$\begin{array}{l}\text { Unethical } \\
\text { expectations }\end{array}$} & conceal or silent about risks of product/service use & 0 & 9 & 91 \\
\hline & $\begin{array}{l}\text { conceal or silent about features of product/service that may } \\
\text { discourage a potential customer from purchase }\end{array}$ & 2 & 19 & 79 \\
\hline & $\begin{array}{l}\text { ignore inconvenient questions, remarks and complaints of } \\
\text { customers }\end{array}$ & 2 & 23 & 75 \\
\hline & $\begin{array}{l}\text { promote services of travel agencies by reducing the value and } \\
\text { importance of competition }\end{array}$ & 9 & 30 & 61 \\
\hline & $\begin{array}{l}\text { perform the tasks although I notice irregularities in the required } \\
\text { manner of execution }\end{array}$ & 9 & 60 & 31 \\
\hline
\end{tabular}

survey, it is on average nearly a quarter of employees in travel agencies in Novi Sad. Although 94\% of respondents said they would never speak ill of competition (Table 2), more than one-third of them said that they promote services of travel agency they are working for by reducing the value and importance of competition (Table 3). Surprisingly, $9 \%$ of employees must always promote services of their travel agency by reducing the value and importance of competition, 30\% implement such marketing policy sometimes.

Perhaps the best image of the internal policy of travel agencies in Novi Sad, which is based on the nature of the relations between the company and its employees and resolving ethical issues that arise from that relationship, give answers of the last survey question "To what extent, are employees of travel agencies expected to perform the tasks albeit they notice irregularities in the required manner of execution". Only one third of employees involved in the research believe they are never expected to the tasks although they notice irregularities in the required manner of execution. More than a half of employees, or $60 \%$, believe they disregard fundamental moral values and perform assigned duties sometimes albeit they perceive irregularities in the required manner of execution just because it is required, while $9 \%$ believe they are always forced to take such action just because it is a policy of TA they work for.

\section{Results of t-tests (paired samples)}

The results in Table 4 indicate no statistically significant difference between ethical personal attitudes of employees in travel agency and ethical business conduct that travel agency management imposes $(\mathrm{p}=0.088$; $\mathrm{t}=1.742$ ). Also, there is no statistically meaningful difference between personal attitudes of employees about their unethical conduct in travel agency and unethical business conduct expected by travel agency management $(\mathrm{p}=0.230, \mathrm{t}=-1.216)$. Based on these results, it can be concluded that the personal ethics is in accordance with the management ethics.

However, when analyzing Table 2, it can be seen that $94 \%$ of employees have never spoken bad of the competing travel agencies to achieve the success of the travel agency he/she works for, while $39 \%$ of employees (Table 3) consider that sometimes or always they are expected to promote travel agencies' services in such a way to reduce the value and importance of competing travel agencies' services. Also, it can be seen that $55 \%$ of the respondents stated they would never obey the authority when it is obvious unethical behavior (Table 2), while $69 \%$ of the respondents be-

Table 4. Testing the difference between employee attitude and business conduct expected by travel agencies' management

\begin{tabular}{|l|l|c|c|c|c|c|}
\hline Pair & Personal attitude - expectations of management & $\mathbf{M}$ & $\sigma$ & $\mathbf{t}$ & df & P \\
\hline \multirow{2}{*}{ Pair 1 } & Ethical conduct of employees & 1,2319 & 0,20863 & 1,742 & 46 & 0,088 \\
\cline { 2 - 7 } & Ethical expectations of management & 1,1489 & 0,23113 & & & \\
\hline \multirow{2}{*}{ Pair 2 } & Unethical conduct of employees & 2,5745 & 0,28777 & $-1,216$ & 46 & 0,230 \\
\cline { 2 - 7 } & Unethical expectations of management & 2,6340 & 0,29582 & & & \\
\hline
\end{tabular}

Note: $M$ - mean, $\sigma$-standard deviation, $t$ - value t statistic, $d f$ - degrees of freedom, $p$-level of significance $(p \leq 0,05)$ 
Table 5. Testing the difference between specific pairs of employees' personal attitudes and related business conduct expected by travel agencies' management

\begin{tabular}{|c|c|c|c|c|c|c|}
\hline \multicolumn{2}{|c|}{ Personal attitude - expectations of management } & M & $\sigma$ & $\mathrm{t}$ & df & $\mathbf{P}$ \\
\hline \multirow[b]{2}{*}{ Pair 1} & $\begin{array}{l}\text { I bad-mouth competition in order to achieve success } \\
\text { of my travel agency }\end{array}$ & 2,91 & 0,351 & 3,554 & 46 & 0,001 \\
\hline & $\begin{array}{l}\text { By doing my daily work tasks I am expected to } \\
\text { promote services of my travel agency by reducing } \\
\text { the value and importance of competition }\end{array}$ & 2,53 & 0,654 & & & \\
\hline \multirow[b]{2}{*}{ Pair 2} & $\begin{array}{l}\text { I blindly obey authority even when it is obviously his } \\
\text { misconduct }\end{array}$ & 2,49 & 0,621 & 2,009 & 46 & 0,050 \\
\hline & $\begin{array}{l}\text { By doing my daily work tasks I am expected to } \\
\text { perform the tasks although I notice irregularities in } \\
\text { the required manner of execution }\end{array}$ & 2,23 & 0,598 & & & \\
\hline
\end{tabular}

Note: $M$ - mean, $\sigma$-standard deviation, $t$-value t statistic, $d f$-degrees of freedom, $p$-level of significance $(p \leq 0,05)$

lieve that they are expected to perform assigned tasks even when they noticed irregularities in the management required manner of execution (Table 3 ).

The results of t-test paired samples in Table 5 show that with $95 \%$ accuracy the abovementioned differences in personal attitudes of employees and travel agen- cies management expectations are statistically significant (pair 1: $\mathrm{p}=0.001, \mathrm{t}=3.554$; pair 2 : $\mathrm{p}=0.050, \mathrm{t}=2.009$ ). Based on the average score and t-test results, it can be concluded that the employees in travel agencies are ready to act in an ethical manner, although it is sometimes the opposite of management expectations.

\section{Conclusions}

A number of findings have emerged from this study. First of all, as for the employees, there is certain contradiction in perception of their own ethical behavior. On the one hand, two-thirds of the respondents consider that they always behave towards consumers in a manner that contributes to a positive image of the travel agency. On the other hand, $57 \%$ of the respondents always or sometimes present travel agencies products better than they really are. This contradiction shows that the management of travel agency is not sufficiently engaged in the management of human resources, including education in the field of business ethics and professional tasks in general. In accordance with previous findings, employees in travel agencies are explicitly or implicitly given the tasks, and respectively they are expected to behave in a manner that will contribute to better travel agencies business results, which often or sometimes means ignoring not only business ethics but also personal ethics. This further indicates that the travel agencies included in this research have not considered business ethics as a tool for achieving a competitive advantage. Instead of encouraging the principles of business ethics, as a basis of business climate in organization, travel agencies management in fact, impose unethical behavior of employees. The results of this study indicate that if there are no workshops and regular meetings to discuss ethical dilemmas that employees face within their work, it comes at the very least, to confusion within the team in terms of standards of value and norms of desirable behavior.
As employees in travel agencies in this sample are mostly younger people and with a relatively short work experience, their education in the field of business ethics, as well as in addressing the various dilemmas of professional practice in tourism is of particular importance. Open discussion on ethical issues contributes to the creation of the collective group conscience as the strongest ally in making moral decisions. In this way, an ethical business culture can be accepted by the organization and incorporated into the mode of working. Moreover, management of business ethics in travel agency business requires a systematic approach starting from academic level to the organizations' policy that is expected standards of business conduct. Jakopec and Susanj (2014) emphasize that it is not enough just to develop fair systems and processes for managing people, but it is necessary that those systems and processes are also fairly and consistently implemented in practice by managers at all levels of the hierarchy. Responsibility entails a voluntary action that is situated beyond juridical obligations, without contradicting them. However, each step should be in accordance with legislative standards, while recognition and resolution of potential ethical problems in early stage as well as sanction of individual unethical behavior are invaluable.

In Serbia as a country in transition, laws are changing and legal procedures occur in almost all areas of life and work. It should also be borne in mind that the whole socio-economic system is in transition, and all 
people, especially employees are required to adapt to new norms and rules of conduct. This relates also to the field of tourism, in which, as it can be concluded from this research, the real behavior of employees, and especially management often deviates from the principles of business ethics. This opens up possibilities for research in other dimensions of tourist business, not just business ethics as important prerequisites for travel agencies successful operation (quality tourism products, customer satisfaction, improve the competitiveness of travel agencies, etc.).

Based on the average score and t-test results, it can be concluded that the employees of travel agencies in Novi Sad are prepared to act in an ethical manner, although it is the opposite of management attitudes in specific situations. The question is why, and therefore, there is a need to undertake research on this issue in the future. Further, with regard to the expected behavior of employees by management in travel agencies, the question is whether these expectations are explicitly presented by the management or the employees themselves have come to such conclusions, which could also be the subject of a subsequent study. It is also important to examine the existence of codes of ethics in organizations and how they are designed: as an informative and educational tool, as a standard of behavior (verbal and nonverbal) and / or as a means of protecting employees.

Even though every questionnaire have statement about the anonymity during the participation in the survey, employees are sometimes afraid that their supervisors would read those questionnaires and that might lead to their dishonesty during the participation in the study. However, this can be a limitation and questionable in every survey conducted among employees in an organization.

This study makes a valuable contribution to theory building and practice in the field of business ethics in tourism, especially in transitional economies, such as Serbia. Research into the ethical approaches of tourism managers and employees assists in ensuring more appropriate, or at least better prepared, students join tourism organizations. Furthermore, this study supports the necessity of systematic approach to management of business ethics, starting from academic level to the organizations' policy. Finally, these findings could now be usefully explored in a variety of tourism/hospitality industry employment domains.

\section{Acknowledgement}

This study was supported by the Serbian Ministry of Education, Science and Technological Development of Republic of Serbia (Project III 43005).

\section{References}

Arthaud-Day, M. L. (2005). Transnational corporate social responsibility: A tri-dimensional approach to international CSR research. Business Ethics Quarterly, 15(1), 1-22.

Belás, J. (2012). Social responsibility and ethics in the banking business: Myth or reality? A case study from the Slovak Republic. Economic annals, 57(195), 115-137.

Blešic, I., Dragin, A., Markovic, J., Deri, L., \& Cerovic, S. (2014). Relationships among shopping quality and corporate social responsibility of shopping centers and consumer satisfaction: Case from Novi Sad (Serbia). Amfiteatru Economic Journal, 16(35), 415-430.

Botescu, I., Nicodim, L., \& Condrea, E. (2008). Business ethics and the social responsability of the company. The Amfiteatru Economic journal, 10(23), 131-135.

Bowen, H. R. (1953). Social responsibilities of the businessman. New York: Harper \& Row.
Carroll, A. B. (1991). The pyramid of corporate social responsibility: Toward the moral management of organizational stakeholders. Business horizons, 34(4), 39-48.

Briedenham, J. (2004). Corporate social responsibility in tourism: A Tokenistic Agenda? Focus, 52(11).

Budeanu, A. (2005). Impacts and responsibilities for sustainable tourism: a tour operator's perspective. Journal of cleaner production, 13(2), 89-97.

Connock, S., \& Johns, T. (1995). Ethical leadership. London: Cromwell Pres.

Daft, R. L. (2006). The new era of management. New Delhi: Thompson Corporation, $847 \mathrm{pp}$.

Davis, K., \& Blomstrom, R.L. (1975). Business and society: environment and responsibility. New York: McGraw-Hill.

De George, T. R. (1987). The status of business ethics: past and future. Journal of Business Ethics 6, 201-211.

De George, T. R. (2003). Business ethics. Belgrade: Filip Visnjic, 652 pp. (in Serbian) 
Drummond, J., \& Bain, B. (2001). Business ethics. Belgrade: Clio (in Serbian)

Enghagen, L. K., \& Hott, D. D. (1991). Students' perceptions of ethical issues in the hospitality and tourism industry. Hospitality Research Journal, 15(2), 41-50.

Enghagen, L. K. (1990). Ethics in hospitality/tourism education: A survey. Hospitality Research Journal, 14(2), 113-118.

Fennell, D. A., \& Malloy, D. C. (1999). Measuring the ethical nature of tourism operators. Annals of Tourism Research, 26(4), 928-943.

First International Congress on Ethics and Tourism (2011). Available at: http://www.ethicsandtourism. com (10.09.2012).

Fisher, J. (2003). Surface and deep approaches to business ethics. Leadership \& Organization Development Journal, 24(2), 96-101.

Frunza, S. (2011). On the need for a model of social responsibility and public action as an ethical base for adequate, ethical and efficient resource allocation in the public health system of Romania. Revista de cercetare si interventie sociala 33, 178-196.

Global Code of Ethics for Tourism. (1999). Available at: http://ethics.unwto.org/en/content/global-codeethics-tourism (10.09.2012).

Goldman, H. A. (1980). The moral foundations of professional ethics. Totowa: Rowan \& Littlefield, 292 pp.

Hall, S. J. (1992). The emergence of ethics in quality. Ethics in hospitality management: A book of readings, 1-2.

Hudson, S., \& Miller, G. (2005). Ethical orientation and awareness of tourism students. Journal of Business Ethics, 62(4), 383-396.

Jakopec, A., \& Sušanj, Z. (2014). Effects of (Mis) alignment between supervisory and organizational justice. Društvena istraživanja: časopis za opća društvena pitanja, 23(4), 615-637.

Jovičić, A., Pivac, T., \& Dragin, A. (2011). Ethical conduct of employees in tourist organizations in Novi Sad (Serbia). Turizam, 15(4), 135-147.

Karpati, T. (2001). Ethics in business. Osjek: Grafika.

Kim, J.E. (2009). Understanding Corporate Social Responsibility in the Tourism Industry ( $\mathrm{PhD}$ thesis). University of Florida.

Kotler, F. (2003). How to create, control and dominate the market. Novi Sad: Adizes, 272 pp.

Official Gazette of the Republic of Serbia (62/14, 6/16, 44/18): Law on Consumer Protection of Republic of Serbia. Available at : http://www.turizam.merr.gov. rs/images/stories/materijal/Zakon\%200\%20zastiti\%2opotrosaca.pdf (05.09.2012).

Official Gazette of the Republic of Serbia (36/2010): Law on the Prohibition of Abuse at Work of the Republic of Serbia
Official Gazette of the Republic of Serbia (36/o9, 88/10, 99/11,93/12, 84/15, 83/18): Law on Tourism of Republic of Serbia. (2010). Available at: http://www.turizam.merr.gov.rs/images/stories/materijal/pravilnici\% 2olat/ZA KON\%20O\% 2oT URIZMU.pdf (05.09.2012).

Lewis, P. V. (1985). Defining "business ethics": Like nailing jello to a wall. Journal of Business ethics, 4(5), 377-383.

Lovelock, B. (2004). New Zealand travel agent practice in the provision of advice for travel to risky destinations. Journal of Travel and Tourism Marketing, 15(4), 259-279.

Lovelock, B. (2008). Ethical travel decisions travel agents and human rights. Annals of Tourism Research, 35(2), 338-358.

McWilliams, A., \& Siegel, D. (2001). Corporate Social Responsibility: A Theory of the Firm Perspectives. Academy of Management Review, 26(1), 117-127.

Miller, G. (2001). Corporate responsibility in the UK tourism industry. Tourism Management 22(6), 589598.

Minciu, R. (2008). Codul global de etică în turism Stadiul de implementare (Aspects of the implementation degree of the World code of ethics in tourism). Amfiteatru Economic, 10(23), 66-71.

Ministry of Finance and Economy (2010). Report on the Work of Tourist Inspection. Available at: http://www.turizam.merr.gov.rs/images/stories/turisticka\% 2oinspekcija/izvestaji/Izvestaj\%200\%20 radu\%2oSektora\%2oturisticke\%2oinspekcije $\% 20$ u\%202010.\%2ogodini.pdf (05.11.2011).

Mišković, I. (2012). Ethics in providing tourism services by travel agents in Serbia. Turizam, 16(1), 2028.

National Association of Travel Agencies in Republic of Serbia (2011). Members of National Association of Travel Agencies in Republic of Serbia. Available at: http://www.yuta.rs/sr/yuta/turisticke_agencije. asp (28.11.2011).

Nordstrom, K.A., \& Ridderstrale, J. (1999). Funky business, talent makes capital dance. Stockholm: Bookhouse Publishing, 288 pp.

Richter, L. K., \& Richter, W. L. (1999). Ethics challenges: health, safety and accessibility in international travel and tourism. Public Personnel Management, 28(4), 595-615.

Robinson, D. (2000). Business etiquette: Your complete guide to correct behaviour in business. Belgrade: Economic Review, 124 pp.

Sethi, P.S. (1979). A Conceptual Framework for Environmental Analysis of Social Issues and Evaluation of Business Response Patterns. Academy of Management Review 4(1), 63-74. 
Shaw, W.H. (1991). Business Ethics. Belmont: Wadsworth Inc.

Simat, K., \& Dragin, A. (2012). Poslovna etika-element uspešnog poslovanja turističkih agencija [Business ethics - An element of successful business of travel agencies]. Zbornik radova Departmana za geografiju, turizam $i$ hotelijerstvo, 41(1), 297-309. (in Serbian)

Simat, K., Dragin, A., \& Dragicevic, V. (2012). The institutionalization of business ethics of travel agencies in Serbia. Turizam, 16(3), 113-123.

Smart Kolektiv (2007). Development of CSR. Available at: <http://www.smartkolektiv.org/cms/item/ csr/en/About+CSR/Development+of+CRS.html > (21.04.2011).

Stark, A. (1998). What's the matter with business ethics? Harvard Business Review, May-June. https:// hbr.org/1993/05/whats-the-matter-with-businessethics (21.04.2011)
Ţigu, G., \& Ţuclea, C.E. (2008). Valorile culturale şi morale - determinanţi ai satisfacţiei in consumul touristic [Cultural and moral values - determinants of tourism satisfaction]. Amfiteatru Economic, 23, 30-35.

Trevino, L. K., \& Nelson, K. (1999). Managing business ethics: Straight talk about how to do it right. New York: John Wiley \& Sons Inc, $480 \mathrm{pp}$.

Vallen, G., \& Cadado, M. (2000). Ethical Principles for the Hositlity Curriculum. Cornell Hotel and Restaurant Administration Quarterly, 41(2), 44-51.

Weeden, C. (2002). Ethical tourism: An opportunity for competitive advantage?. Journal of Vacation Marketing, 8(2), 141-153.

Yaman, H. R., \& Gurel, E. (2006). Ethical ideologies of tourism marketers. Annals of Tourism Research, 33(2), 470-489.

Zenisek, T. J. (1979). Corporate social responsibility: A conceptualization based on organizational literature. Academy of management review, 4(3), 359-368. 